\title{
Resource misallocation and mark-up ratios: an alternative estimation technique for Harberger triangles ${ }^{1}$
}

\author{
Mathijs A. van Dijks ${ }^{a}$, Peter A.G. van Bergeijk ${ }^{\mathbf{b}, *}$ \\ "Limburg Institute of Financial Economics (LIFE). Maastricht University, Maastricht, The Netherlands \\ "Ministry' of Ecomomic Affairs, P.O. Box 20101, 2500 EC The Hague. The Netherlands
}

Received 25 September 1996; accepted 18 December 1996

\begin{abstract}
Roeger's method (Roeger, 1995), which analyses the relationship between primal and dual productivity measures, can also be used to directly estimate from readily available data the static welfare loss due to a suboptimal allocation of the factors of production.
\end{abstract}

Keywords: Price mark-up; Allocative efficiency

JEL classification: D61; L60; L70; L80; L90

\section{Introduction}

The ratio between price and marginal cost (the so-called mark-up ratio) is an important indicator for the existence of potential problems related to deviations from an optimal allocation. Consider a representative firm that maximizes its profit $\pi=p(q) \cdot q-c(q)$, where $p$ is price, $q$ is quantity and $c$ is the cost function. The first-order condition implies $p\left(1-\epsilon^{-1}\right)=c_{q}$ and $\epsilon$ is the absolute value of the elasticity of demand that the firm faces. The mark-up $\mu$ is $p / c_{q}=\epsilon /(1+\epsilon)$. If competition is perfect we have $\epsilon=\infty$ (so price equates marginal costs and $\mu=1$ ). Price exceeds marginal costs if competition is imperfect $(\mu>1)$.

The mark-up can be directly related to the static welfare loss (or Harberger triangle) of monopolistic pricing. Harberger's expression for this dead weight loss is $W=\frac{1}{2} \Delta P \Delta Q$, where $\Delta P$ is the difference between the actual (monopoly) market price and the hypothetical price that would result under free competition ( $\Delta Q$ is the difference between the corresponding quantities). For a horizontal marginal cost function and a linear down-sloping demand curve the deadweight loss is $W=\frac{1}{2}(\mu-1) p / \mu$. $\epsilon q(\mu-1) / \mu$, which can readily be expressed in terms of turnover:

$$
W / p q=(\mu-1) / 2 \mu
$$

\footnotetext{
*Corresponding author. Tel.: + 3170 3796379; fax: + 31 70 3797018; e-mail: p.a.g.vanbergeijk@minez.nI.

'This article does not necessarily reflect the opinion of the government of the Netherlands.
} 


\section{Estimation}

Whereas prices can be observed directly, marginal costs can only be estimated indirectly. Following Roeger (1995), we confront residuals in growth accounting that are calculated from the production function (the Solow residual) and the cost function (its dual), respectively. Subtracting the dual residual from the Solow residual yields an equation from which $\mu$ can be estimated directly (Eq. (2)) so that we can calculate the welfare loss $W / p q$.

$$
y_{11}=\hat{g}_{i} x_{i s}+v_{11}
$$

where

$\hat{g}_{1}=1-1 / \mu_{i}$ (to be estimated)

$y_{11}=\Delta Q_{11} / Q_{11}+\Delta p_{11} / p_{i 1}-\alpha\left(\Delta w_{11} / w_{11}+\Delta L_{i 1} / L_{i 1}\right)-(1-\alpha)\left(\Delta r_{i 1} / r_{i 1}+\Delta K_{i 1} / K_{11}\right)$

$i_{11}=\Delta Q_{11} / Q_{11}+\Delta p_{11} / p_{11}-\left(\Delta r_{11} / r_{i 1}+\Delta K_{11} / K_{i 1}\right)$

$\alpha=$ labour share

$v_{11}=$ error term, $v_{11} \sim N\left(0, \sigma_{i}^{2}\right)$

$r_{1}=$ interest rate

$K_{i \prime}=$ capital stock.

Thus we can directly estimate the static welfare loss due to a suboptimal allocation of production factors from readily available nominal observations (capital costs, labour costs and the labour share).

\section{Empirical results}

Table I summarizes ordinary least-squares estimates of Eq. (2) for 12 sectors that represent $53 \%$ of the Dutch economy (differences in the estimation period are due to data (non-)availability). The diagnostic test statistics are quite satisfactory. Particularly good is the equation for the Dutch public utilities which appear to set their prices at twice their marginal costs (note that $97 \%$ of the variance in Eq. (2) is explained for this sector).

Column (2) reports the implied point estimate of the mark-up ratio for each sector. The point estimates, however, may give the wrong message to the users of these econometric findings and hence a cautious approach that does right to the standard errors of the estimates is appropriate (van Bergeijk and Haffner, 1996). For this purpose columns (3) and (4) of Table 1 report the lower limits of two-sided confidence intervals of $95 \%$ and $99 \%$, respectively. From these lower limits it can be concluded that the free competition model may actually be a reasonable description for the Dutch automobile and transport equipment industry and the Dutch textiles, wearing appareil and clothing industry since the mark-up is hardly statistically different from 1.

The estimated welfare loss (reported in columns (7) and (8) of Table 1) is substantial and well beyond the usual estimates of the Harberger dead weight loss of imperfect competition. The weighted average welfare costs are $15 \%$ of turnover (at the $99 \%$ confidence level we can state that the welfare costs are at least $8 \%$ of turnover).

Like other studies related to the Netherlands, these findings suggest substantial scope for improvement in the Dutch allocation of the factors of production. 
Table 1

Mark-up ratio and static welfare loss in 12 sectors of the Dutch economy (ordinary least squares. 1970-1992)

\begin{tabular}{|c|c|c|c|c|c|c|c|c|c|}
\hline \multirow[t]{2}{*}{ No. } & \multirow[t]{2}{*}{ Sector } & \multirow{2}{*}{$\begin{array}{l}\text { Estimation } \\
\text { period } \\
\text { (1) }\end{array}$} & \multirow{2}{*}{$\begin{array}{l}\mu \\
\text { (2) }\end{array}$} & \multirow{2}{*}{$\begin{array}{l}\mu_{1,5} \\
\text { (3) }\end{array}$} & \multirow{2}{*}{$\begin{array}{l}\mu_{9,9} \\
\\
\text { (4) }\end{array}$} & \multirow{2}{*}{$\begin{array}{l}R^{2} \text {-adj } \\
\text { (5) }\end{array}$} & \multirow{2}{*}{$\begin{array}{l}\text { DW } \\
\text { (6) }\end{array}$} & \multicolumn{2}{|c|}{$\begin{array}{l}\text { Implied welfare } \\
\text { cost in per } \\
\text { cent of turnove } \\
\text { based on }\end{array}$} \\
\hline & & & & & & & & $\begin{array}{l}\mu \\
(7)\end{array}$ & $\begin{array}{l}\mu_{1, y} \\
(8)\end{array}$ \\
\hline 1 & Public utilities & $70-90$ & 2.13 & 1.96 & 1.91 & 0.97 & 2.07 & 26.5 & 23.8 \\
\hline 2 & Chemical and rubber products & $71-90$ & 2.13 & 1.47 & 1.34 & 0.53 & 2.46 & 26.5 & 12.7 \\
\hline 3 & Agriculture, forestry and tishing & $70-92$ & 1.59 & 1.34 & 1.27 & 0.57 & 1.6 .3 & 18.6 & 10.6 \\
\hline 4 & $\begin{array}{l}\text { Food, beverage and tobacco) } \\
\text { industry }\end{array}$ & $71-90$ & 1.56 & 1.31 & 1.26 & 0.68 & 2.35 & 17.9 & 10.3 \\
\hline 5 & Electrotechnical engincering & $71-90$ & 1.54 & 1.27 & 1.20) & 0.41 & 2.40 & 17.5 & 8.3 \\
\hline 6 & Wood and building materials & $71-90$ & 1.4 .3 & 1.25 & 1.20 & 0.60 & 1.88 & 15.) & 8.3 \\
\hline 7 & Paper, printing, publishing & $71-90$ & 1.32 & 1.19 & 1.15 & 0.6 .3 & 2.56 & 12.1 & 6.5 \\
\hline 8 & $\begin{array}{l}\text { Construction and installation } \\
\text { on constructions }\end{array}$ & $7(0-90$ & 1.32 & 1.17 & 1.1 .3 & 0.60 & 1.27 & 12.1 & 5.8 \\
\hline 9 & $\begin{array}{l}\text { Metal industry, machinery } \\
\text { and instruments }\end{array}$ & $71-90$ & 1.28 & 1.15 & 1.11 & 0.28 & 2.72 & 10.9 & 5.0 \\
\hline 10 & $\begin{array}{l}\text { Automobile industry and } \\
\text { transport equipment }\end{array}$ & $71-90$ & 1.28 & 1.01 & 0.95 & 0.14 & 2.01 & 10.9 & (). $(0$ \\
\hline 11 & $\begin{array}{l}\text { Transportation and } \\
\text { communication }\end{array}$ & $70-92$ & 1.23 & 1.12 & 1.09 & 0.41 & 2.30 & 9.3 & 4.1 \\
\hline 12 & $\begin{array}{l}\text { Textiles, wearing appareil } \\
\text { and leather }\end{array}$ & $71-90$ & 1.20 & 1.05 & 1.01 & 0.21 & 2.01 & 8.3 & 0.5 \\
\hline
\end{tabular}

Note: All mark-ups are significantly larger than 1 at the $95 \%$ confidence level and better. $\mu_{1,2}$ and $\mu_{2,4}$ are the lower bounds of the two-sided confidence interval of the estimated mark-up if we require $95 \%$ and $99 \%$ confidence. respectively.

Sources: Central Planning Bureau (data set on disk) and Central Bureau of Statistics Nattional Accounts 1993 Table H5. p. 76.

\section{References}

Bergeijk. P.A.G. van. Haffiner, R.C.G., 1996. Privatization. Deregulation and the Macroeconomy: Measurement. Modelling and Policy. Edward Elgar, Cheltenham. UK.

Roeger, W.. 1995. Can imperfect competition explain the difference between primal and dual productivity measures? Estimates for U.S. manufacturing. Journal of Political Economy 103 (2), pp. 316-330. 